\title{
中国雲南省の不動産事情・健康産業開発状況 視察報告
}

\author{
白川 貴子 獨協大学非常勤講師 \\ 関岡 千賀 株式会社大京アステージ
}

\section{1.はじめに}

2018年度、日本不動産学会は中国の雲南省を訪れ、 2019年 3 月 4 日から 8 日まで、高齢者向け施設や住宅プ ロジェクトの事情調査を実施した。中国では、一人っ子 政策の結果として急ペースで進んでいる高齢化にともな い、今後ますます大きな市場に発展すると見込まれる高 齢者介護ビジネスが成長している。昆明市はシニア層が 暮らしやすい温暖な気候と自然環境に恵まれており、政 策的な誘導も相まって、高齢者に向けた高級保養施設の 開発や、漢方薬品原材料生産基地など健康産業の育成、 住宅建設計画に力を入れている。そこで、超高齢化社会 を迎える中国での不動産開発の動向、地域発展戦略の動 向などについて視察を行ってきた。以下にその概要を報 告する。

\section{2 。雲南省、昆明市について}

雲南省は中国の南西部に位置し、ミャンマー、ベトナ ム、ラオスと国境を接している。豊かな資源に恵まれ、 多数の少数民族（全国56民族のうち25の民族）が暮らし ていることでも知られている（ちなみに中国共産党の ウェブサイトによれば、中国全土で発見されている鉱物 種類の $93 \%$ を有し、植物資源も全国で種類が最も多い)。 省都の昆明市は海抜 $1,890 \mathrm{~m}$ の広大な盆地にあり、夏は 涼しく冬は温かい穏やかな気候から、中国では「春城」 （一年中春の街）と呼ばれて親しまれている。現在の人 口は 750 万人。 2015 年の約 658 万人から大幅に増えている ことがうかがわれる。地政学的にも交易の要所にあり重 要な地域であるため、2013年より中国政府が打ち出して いる「一带一路」のシルクロード経済圈構想においても、 東南アジアへの要衝としてさらなる発展が期待されてい る。高速道路や新幹線の開通など、この数年間で交通イ ンフラの整備が急ピッチで進んでおり、国内外への移動 が飛躍的に便利になった。長距離交通網だけでなく、昆 明市内でも現在開通している地下鉄 2 線に加え、2020年 までに 6 線が開通することが見込まれている。

\section{3. 現地到着（3月 4 日）}

調査団は総勢 9 名。それぞれに羽田空港、関西空港、 福岡空港を出発し、広州で国内線に乗り継いで、昆明の

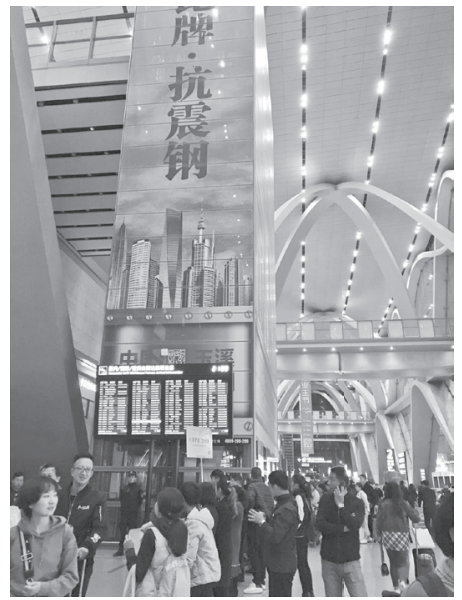

写真A-1：昆明長水国際空港

長水国際空港で集合した。【写真A-1】広州では乗り換 える際の入国審查で指紋採取が義務化されていたことに 驚かされた。空港で、今回の視察で大変お世話になった 沃（よく）永華（えいが）氏（浙江省沃華環境科技有限 会社会長）とガイドの馮（ひょう）雲昆氏はじめ王龍超 氏 (卓一源〈深圳〉実業有限会社会長)、李軍氏（同社 長) の出迎えを受け、そこから車に分乗し、夜道を走る こと約 1 時間半、町の灯りが遠ざかり、媣夜をまわる頃 に、80kmほど離れた石林県のホテルに到着した。

\section{4. 調查初日（3 月 5 日）}

ホテルは、主に台湾資本で開発され、温泉や保養客の 中長期用宿泊施設などを備えた 4 万 8,000 haの広大な複 合施設、「杏林大観園」の中にあった。第 1 日目は、朝 食後、敷地内の「中医文化展覧館」を訪れる。民族衣装

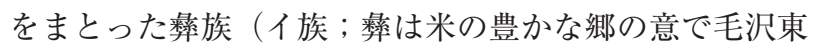
が与えた部族名）のガイドさん【写真A-2】から説明を 受けながら、《歷代經典處方長廊》、《歧黃之術館》、《湏南本 草館》、《中華醫史館》、《中華藥史館》、《雲南少數民族醫藥 館》を見学した。漢方の原材料は圧巻の展示で、棚には ガラス瓶に入った動植物、乾物、鉱物類が整然と分類さ れて 1,800 本以上並び、鉢植えや水栽培の植物がずらり と陳列されていた【写真A-3】。少数民族が多い雲南省 ではおのおのの伝統的な医術の知恵が継承されていると いう。資源の豊かさでも群を抜いているので、中国で使 われている漢方薬の原材料の $55 \%$ 、600種類を超える材 


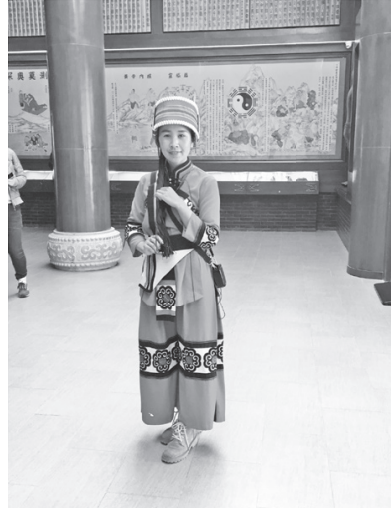

写真A-2：イ族の衣装をまとつ た可憐な女性ガイド

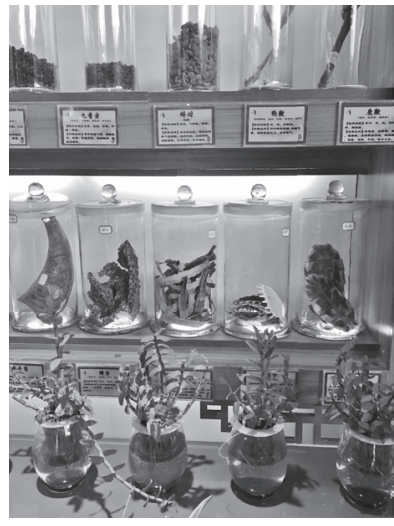

写真A-3：漢方の原料の展示 の一部
料が雲南省のものだそうだ。昼食は空港到着時から夜遅 くまで同行してくださり、現地の起業家 2 名と一緒に案 内役を務めてくださった沃永華氏のご厚意により、園内 で栽培された材料による本家本元の薬膳料理を味わった

午後は「生態園」(果樹園) を訪ね、作物の栽培状況を 見学する。【写真B-1、B-2、B-3】収穫期ではなかった が、桃、桜桃、葡萄、キウイ、プラムやミニトマトなど が有機栽培されていた。滞在客は電話一本で園内を走る 電気自動車による果実のデリバリーも利用でき、客室で 季節の味覚を楽しむことができるそうだ。耕作が難しい 土壌なので以前はソバやトウモロコシが主要作物だった が、今では台湾の技術指導を受け、この土地特有の赤土 と高原気候を生かした新しい農法の開発が進んでいた。 夕バコも基幹産業のひとつになっている。ちょうどビ ニールハウスでは真っ赤に熟れたイチゴの最盛期。害虫 よけにニンニクを共生栽培する無農薬農法が行われてい た。広大な土地が広がっているのでどこへ行くのにも遊 園地のミニ電車のような電気自動車に乗って移動しなく てはならない。続けて「杏林禅寺」を見学。文化大革命 時に破壊された「薬王廟」を再建したもので、医術に対 する梁い畏敬から、188体も名医の像が祀られていた。

\section{5 。調查第 2 日目（3 月 6 日）}

9 時にホテルを出発し、施工中の「高齢者向け住宅」 エリアを訪ねる。まだ内装工事中だったが、メゾネット 形式の一室に入ると、手すりの下地、段差の無い床、壁 に緊急呼び出し用のパネルなどがあり、脚力や握力が衰 えた高齢者のための住まいであることがうかがえた。階 段はコンクリート。上り下りする体力は求められるのだ ろう。トイレや洗面台なども、車椅子では使いにくいよ うに見えた。次に見学したシェアハウス型の住居は、二 階に独立した寝室兼居住スペースがあり、そのほかは共 有する設計となっていた。兄弟がいない一人っ子に介護 を頼ることは難しく、若者が都市部に移住してしまう農 村部では特に、高齢者の介護は難しい問題になるとみら れているという。シニア向けの共同生活住宅は、高齢者
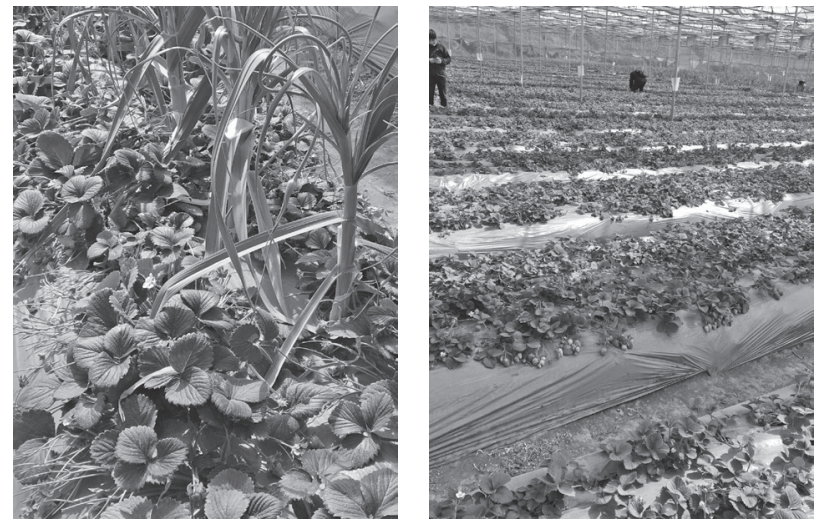

写真B-1、B-2 : イチゴの钦にニンニクが防虫のために植え られていた

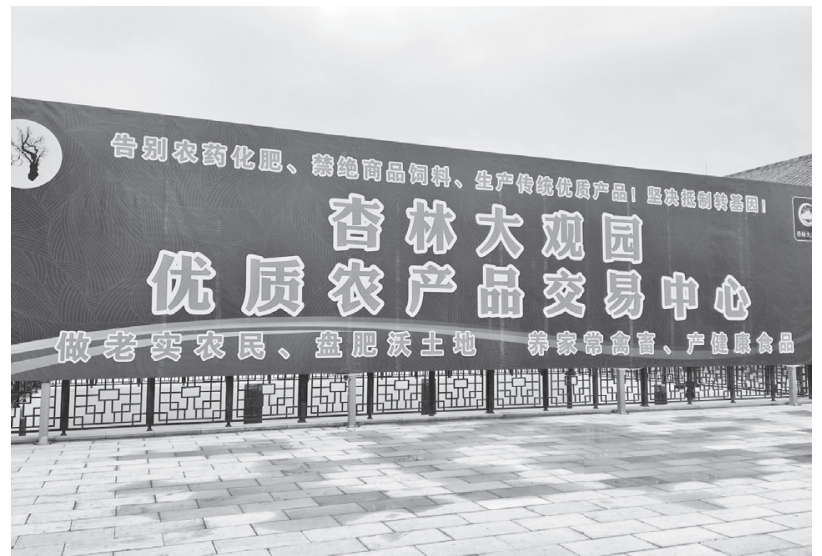

写真B-3 : 化学肥料を使わず、昔ながらの農法で優れた産品 を提供すると謳う、「生態園」の看板

同士で互いを助け合う「老老介護」を可能にするひとつ の方法なのかもしれない。どんな設計であれ、麻雀卓が 置けるように配慮されているところが中国らしかった。

次に、広大なカルス卜地形の「石林風景区」へ。中国 では「天下第一の奇観」と呼ばれ、2007年にユネスコの 自然遺産に登録されてから急激に観光客が増えたそうで、 急峻な滑りやすい岩道を息を切らせて登るあいだも、各 地から訪れた中国人観光客で押すな押すなの賑わいに なっていた。写真C-1、C-2】昼食後は、ロングステイ 型の大型宿泊施設「石泉村度假酒店」で客室を見せても らう。ひとつのコテージに寝室が 5 室あり、 3 家族が同 時に宿泊しても余裕がありそうな広さだった。茶器など 備品のほかに、麻雀卓も（もちろん）設置されていた。 その後は歩き疲れた身体を癒やすべく、風景名勝区の目 玉施設「石海温泉」へ向かう。男女ともに水着を着用し てガウンを羽織り、効能の異なる17種類の露天風呂を楽 しむことのできる大々的な温泉リゾートだ。効能書きの 看板や湯音表示の温度計が備わり、クロークでは履物を あずけて無料でビニールサンダルを貸し出してもらえる。 個人用のカギのほかに係員のカギも必要な二重ロック方 式の脱衣室も、雲囲気は日本とさほど变わらない。温泉 に浸かっていると「崇明島（上海市）」から来たという 3 人連れの女性と一緒になり、「一日いくらで宿泊して 


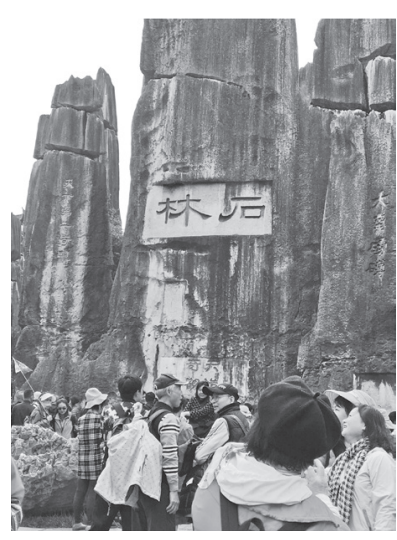

写真C-1：国内の観光客で賑 わう「石林」

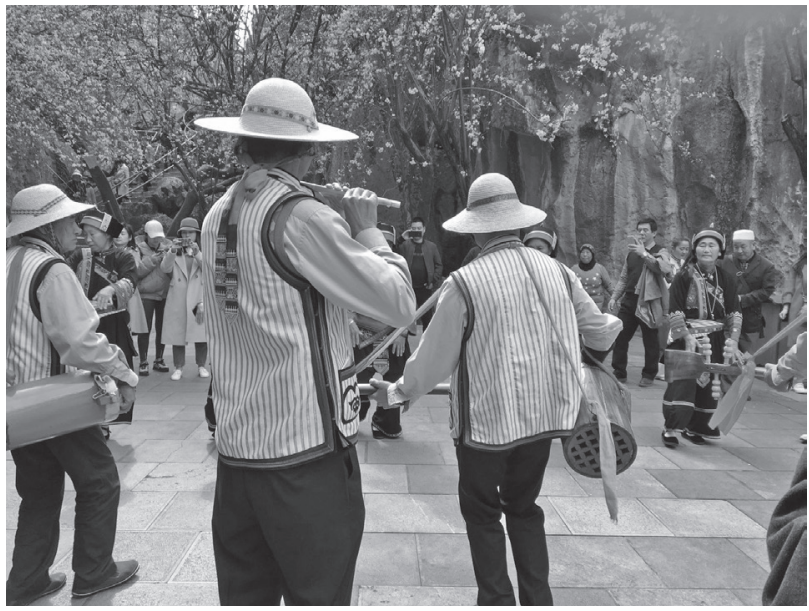

写真C-2：イ族の伝統音楽と踊りも園内で披露されていた

いるの?」という質問を受けてしばし歓談。彼女たちの 宿泊費は 1 日およそ一人 100 元だという。日本との金銭 感覚のギャップは、本当になくなったと痛感した。

\section{6. 調查最終日（ 3 月 7 日）}

いよいよ最後の日。昆明市で大規模な不動産開発に携 わっている「怡寧地産有限公司（Yining Real Estate Development, Co.)」を訪問するため、8 時にホテルを 出発して一路、高速道路を昆明に向かう。都会に近づく につれ、見上げるばかりの高層ビル群が増えてくる。 【写真D-1、D-2】10時過ぎ、到着すると、会長（董事長） の卒（びい）龍（ろん）氏、社長の卒胜（せい）氏をは じめとする関係者が表通りに整列して一行を待ち受けて おり、一人ひとりに握手の挨拶をする中国式の歓迎を受 けた。【写真E】2007年に設立したこの不動産会社は、昆 明市とその近郊で大規模都市開発を行い、商業施設複合 型タワーマンション群の建設を積極的に展開している。 本社の前で挨拶を済ませてから、徒歩で移動し、昆明市 中央部の開発区「春城慧谷」を見学する。開発総面積は $27 \mathrm{ha}$ 、建築延床面積 127 万 $\mathrm{m}^{2}$ 。区画内には配達など住人 へのサービスが充実したスーパーマーケットのほか、日 本のように低層階に店舗や飲食店が入っている商業施設、 幼稚園や小学校、オフィス、銀行など、複合的な機能を
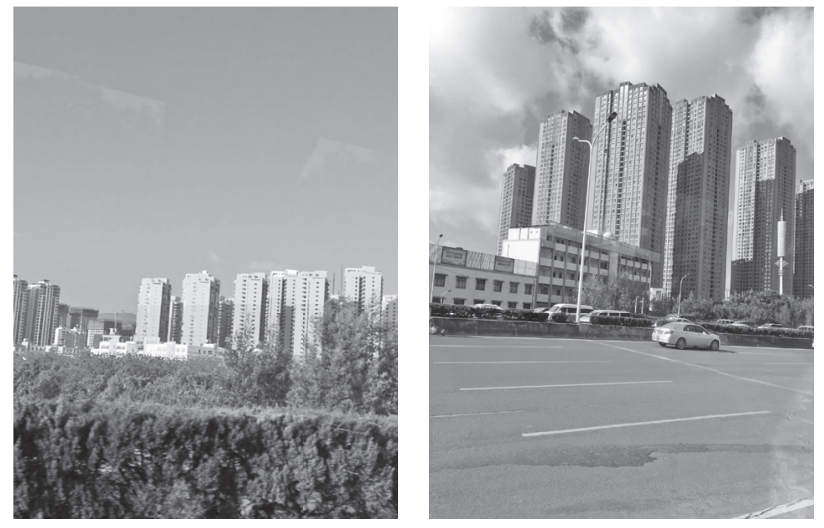

写真D-1、D-2：石林から昆明の中心部に向かうと、高層ビ ル群が現れた

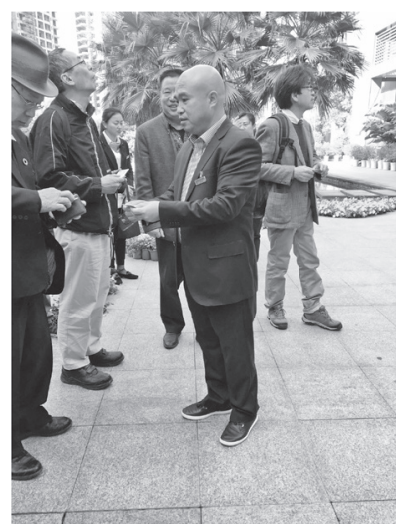

写真E : 視察団を迎える、「寧 地産有限公司」董事 長の卒龍氏

備えた新しい形式の都市住宅が完成していた。すでに第 3 期まで建設・販売が終了しており、第 4 期の延床面積 70 万 $\mathrm{m}^{2}$ 、住戸 1 万 7,000 戸の、商業施設、スポーツジム などの複合施設が備わる大規模物件も建設中、2019年 5 月に販売開始が予定されているそうだ。第 1 期に完成し たマンションに住む社員の一室を見学させていただいた。

【写真F-1】部長職についているというそのオーナーは、 社員であることから割安で購入できたそうだが、 $4 \mathrm{LDK} 、 130 \mathrm{~m}^{2}$ の一室に家族 3 人で暮らし、そのほかに も同じ区画にもう 2 室を所有しているそうだ。こうした 物件は相場が上がり続けているので、10年前は $1 \mathrm{~m}^{2} を$ 当たり 3,000 元だった価格が、現在は 1 万 1,000 元になっ ている。 5 年後にはさらに上がり、 2 万元から 3 万元に なるだろうと予想されている。それでも人気が高く、現 在の入居率は $98 \%$ に達し、新規売出し物件も販売を開始 してすぐに完売するという。一戸当たりの面積は $2 \mathrm{DK}$

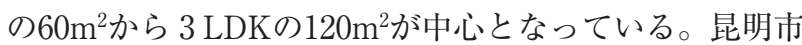
では勤め人の月収が拈よそ 5,000 元と言われるが、ガイ ドの馮氏の意見では、実際には2,000元から3,000元の人 も多いそうだ。 5,000 元でも $1 \mathrm{~m}^{2}$ 当たりの単価が給料の 2 力月分を超え、 $60 \mathrm{~m}^{2}$ を購入すれば 120 力月、10年分の 給料に相当する計算だ。市内中心部の複合型タワーマン ションに住むことができるのは、ある程度資産のある層 


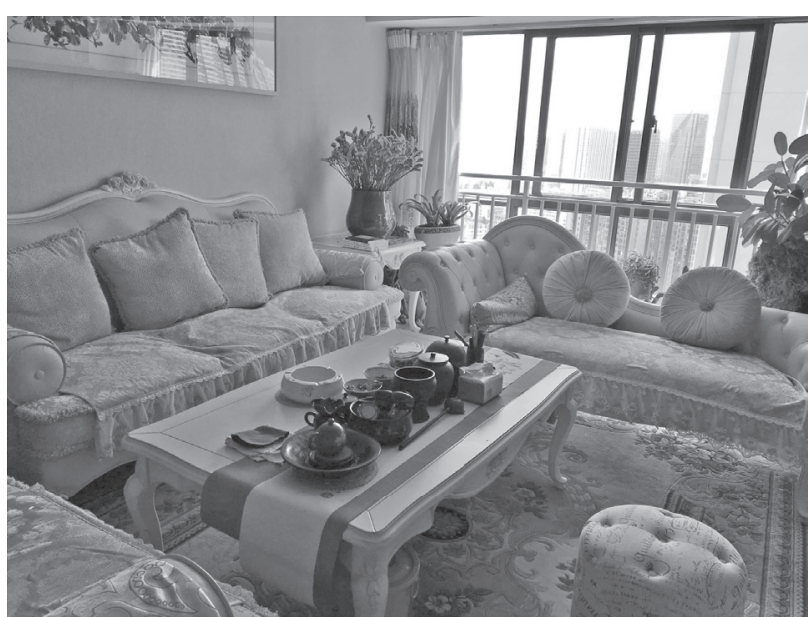

写真F-1：4LDK、130m²に家族 3 人が暮らすマンションの一室

に限られると思われる。

昼食をはさみ、午後は車で郊外にある西山区へ向かう。 山道を走り、森林公園となっている小高い丘の上から、 湖を囲む緑とその向こうに広がる遠い町並みを眼下に見 渡した。卒会長の説明では、下方に見えていた湖を中心 とする緑豊かな679haの一带に、開発費300億元を投入 し、高齢者向けに、建設用地433ha、延床面積500万 $\mathrm{m}^{2}$ の養老施設を建設する計画（「花紅園」開発プロジェク 卜）であるという。建設予定地は昆明の中心部から混雑 なしの場合でもバスで20分程度の距離だが、プロジェク 卜に合わせてここまで鉄道と高速道路を整備し、10分ほ どに短縮するので、交通は非常に便利になる。ここに高 齢者が暮らすための、排水や廃裹物を考虑した環境循環 型の大規模複合型開発を実現させたいという構想だった。 【写真G】現地見学後は社屋に戻り、30人ほどが着席で きる巨大なガラステーブルを囲んで、補足説明のプレゼ ンや質疑応答をする時間が設けられた。たとえば、土地 が所有できない中国では使用権がついており、住宅地の 使用権の期間70年が終了した後はどうなるのかという質 問に対しては、先例がないため不明だが問題なく更新で きるだろうと説明があった。マンションの管理費につい ては、管理子会社を設けて徴収しているが、実際上は分 譲会社が管理も請け負うかたちで、入居条件に記載され た了解にもとづき、10年分を前払いで払ってもらう。 $1 \mathrm{~m}^{2}$ 当たり 5 元なので負担にはならず、未納者はほと んどいないそうだ。日本で設けられている「区分所有 法」標準管理規約」といった集合住宅に関連する法や基 準は明確に設けていないようだ。開発予定地を見学した 西山区「花紅園」の開発プロジェクトについては、海外 の技術やノウハウを積極的に取り入れたいと会長の卒氏 が希望を述べ、日本から排水や廃棄物処理の環境配慮に

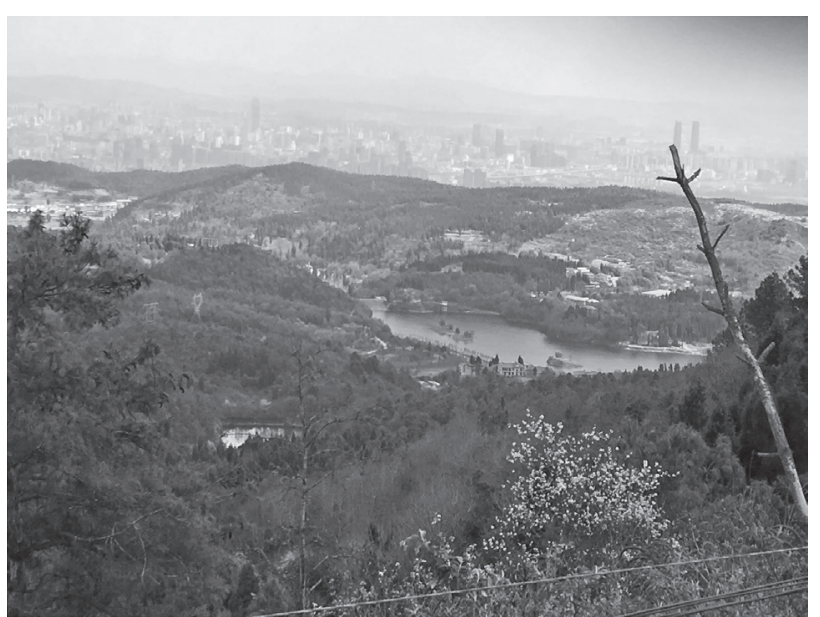

写真G：広大な循環型複合施設の予定地

ついて、また、設計・高齢者向け設備についての技術や ノウハウの協力を得たいと語った。会議室では雲南省産 の薬草、松茸の他、野生のハチミッを全世界に届けたい という生態農業の専門家の孫濤氏（緑春福瑞生態農業発 展有限会社会長）によるプレゼンや、丸い小さなウリの ような、健康長寿の為には一定量の摂取が求められる栄 養成分のセレン（Se）をコメ平均の300倍近く含む果物 (周和平人参果) を広めたいという環境保全型農法の起 業家で空港で出迎えをしてくれた王龍超氏のプレゼンも 行われ、18時ごろに終了する。その後はそのまま上層階 に移動し、全員が着席できる丸テーブルで夕食の馳走に あずかり、正味 3 日間の充実した調查旅行の終わりが飾 られた。

\section{7 。帚国日（3 月 8 日）}

東京、関西方面の一行は早朝 7 時に、九州組はそれよ り少し遅くホテルを出発し、全員が昆明空港から無事に 帰途についた。雲南省と聞けば、少数民族が住んでいる 寒村や風光明媚な観光名所、豊かな資源といった牧歌的 なイメージを思い描いていたが、昆明市は、雲をつかん ばかりの高層マンションが林立していた。都市開発の勢 いはすさまじく、巨大都市に変貌しつつあるようだ。夏 でも涼しく雪はめったに降らず、空気がきれいで、湿度 も低いため関節痛の心配がいらないなどの好条件に恵ま れているのであれば、昆明で老後を過ごすのも悪くない と考える人は多いのかもしれない。またいつか訪れて、 今後の変化を見届けたいと思わされた。

\section{参加者 9 名（五十音順）}

吴 臻／坂西明子／下崎 寞／下村郁夫／城島 博／ 白川貴子 /関岡千賀 $/$ 水鉋揚四郎 / 福井秀夫 